\title{
Research in Textiles
}

I $\mathrm{N}$ a recently issued report on the work carried out in the Clothworkers' Departments, University of Leeds, under a research scheme established in 1928 by means of a grant of $£ 3000$ a year from the Worshipful Company of Clothworkers, reference is made to the value of the scheme not only in promoting a research plan, which has already a number of fundamental discoveries to its credit and holds promise of further work of outstanding scientific and technical importance, but also in providing industry with scientifically trained men. The report presents a survey of the three years' working of the scheme and is not confined to a statement on a single year. It is pointed out that the scheme has led directly to the creation of a school of textile research in Great Britain which has already attracted advanced workers from other countries. It is hoped that the recent creation of an honours degree of B.Sc. in textiles will assist in discovering students who will devote themselves to continuous work in this field, and it is strongly urged that the research grants for fellowships or scholarships in colour chemistry should be put on a permanent basis in 1932. The importance of adequate research scholarships being available in periods of industrial depression is specially stressed.

The survey of work in textile physics stresses the value of the results obtained by the application of $\mathrm{X}$-rays methods, to which frequent reference has been made in Nature. The combined evidence of chemical and X-ray analysis has led to the conclusion that the structure and properties of common industrial fibres are based on three main fundamental principles: long, thin crystalline or pseudo-crystalline particles, with their long dimensions inclined at a constant angle to the fibre axis, as in cotton, or parallel to the fibre axis, as in ramie, silk, wool, etc. If the molecular chains are inextensible the fibres can be stretched only by making the molecular bundles slip over one another, examples being cellulose fibres, natural silk, stretched wool and other animal hairs, and stretched rubber. If, as in cellulose and silk, the straight molecular state is the normal state, there is only a limited power of recovery from extension. If, however, the molecular chains are themselves extensible, as in unstretched wool, hair, and unstretched rubber, the fibres can be stretched to abnormal dimensions and afterwards recover their original length exactly.

Further investigations have shown that by various methods wool can be contracted to half its original length, while X-ray studies on the permanent set of stretched wool and hair have revealed that steam acts on the extended molecules so as to prevent their contraction to the folded state. The process is analogous to the vulcanisation of rubber, and detailed results of the 'setting' of wool by steam will shortly be published. X-ray analysis of fibres has not only supplied strong evidence in support of the chain theory of protein structure but also is now furnishing important information about the actual growth of cellulose in Nature, and X-ray photographs of the wall of Valonia ventricosa promise to throw light on one of the greatest problems in botany and agriculture. X-ray photographs of the structure of feathers have also shown that feathers and tortoise-shell give a common X-ray photograph which is different from that of wool and hair, and accordingly the classification of their fibrous protein with the keratin of wool, hair, horm, etc., in most textbooks is incorrect.

On the physico-chemical side, the studies of the elastic properties of wool which have already indicated the underlying causes of the permanent setting of hair have now led to the discovery, of far-reaching importance for wool-finishing processes, that the "set" imposed at any one temperature is permanent only to water at a lower temperature than that at which it was imposed. This and the subsequent discovery that caustic soda solutions have the same property of being able to eliminate permanent set have led to the development of two new finishing processes for producing crêpon effects.

Investigations on the relation of rigidity to the amount of moisture present in the fibre and to atmospheric humidity showed that while the breaking load of wool fibres is only reduced in the ratio $1.5: 1$ by a change from absolute dryness to saturation with water, the rigidity changes in the ratio $15: 1$, and thus afforded an explanation why artificial humidification is essential for spinning mills but relatively unimportant at other stages of manufacture. Further explanation of variations in the spinning properties of wool has been found in the discovery that the affinity of wool for water decreases as the temperature at which it is dried increases.

These investigations not only make an important contribution to the knowledge of the structure of wool but also afford explanations of important technical points, such as fastness to rubbing. Most wool dyes are smaller in particle size than the pores of the swollen wool fibre and penetrate to the interior of the fibre. Dye molecules or particles which are larger in size than the pores of the swollen fibre can only be absorbed at its external surface, and the dye is accordingly readily removed by rubbing.

Other recent work has shown that acids have the property of attacking and subdividing the micelle structure itself, rendering the fibre easier to stretch. The further discovery that wool is completely immune to attack by acid and alkali over a wide range, known as the $p \mathrm{H}$ stability region, not only affords a striking and independent confirmation of Svedberg's results on soluble proteins, but is also of considerable significance in relation to wool scouring. It has also been possible to establish definitely the nature of one of the linkages in the wool molecule and thus to show that the combination of wool with acids and acid dyes is a strictly chemical process. The further discovery that at high temperatures the wool micelles are sub. divided by water alone has a profound significance for the acid dyeing of wool. Space does not permit further reference to numerous other more technical researches which among other points have established the importance of perfect elasticity as well as surface scale structure for milling shrinkage.

\section{Standardisation of Screw Threads}

$\mathrm{I}^{\mathrm{N}}$ the Human Factor (vol. 6, No. 2) there is an interesting article by W. F. Watson, a working mechanic of thirty years experience, describing the conflict between the duodecimal and decimal systems of measurement in his domain. He surveys the history of the two systems of measurement in the various countries, and the gradual success of the decimal, except in England. He illustrates the trials of the turner and manufacturer, by a study of screw threads.

The first attempt at securing uniformity in screws was made by Sir Joseph Whitworth in 1841, and in the course of twenty years the Whitworth system 
was the recognised standard for general engineering purposes. Prior to that, each firm had its own 'standard' set of screwing tackle, the existence of which made engineering repairs costly and inconvenient. Owing to the pre-eminent position occupied by British engineering, the establishment of a British system was very favourable, and no difficulty was experienced in securing the adoption of Whitworth screws in Germany and the United States.

The two great attacks made on the Whitworth system came from the Franklin Institute in 1864, when the Sellers thread was adopted and recommended to American engineers, and in 1873, when Delisle of Karlsruhe initiated a metric system. In 1918 the International Screw Thread Congress adopted the international metric screw thread. Now the metric system of screw threads is standardised on the continent of Europe, America has its Sellers standard, whilst Great Britain retains the Whitworth system.

It is said that the threads now recognised as standards are included in about eight great systems, but a popular handbook gives details of no fewer than thirty different kinds of screw thread. As an example of the practical confusion arising, Mr. Watson says that if we place side by side a half-inch American screw, an English half-inch screw, and a $12 \mathrm{~mm}$. screw ( $2 \mathrm{~mm}$. pitch), it is not easy to note the difference. The American screw has, however, 13 threads to the inch, the English 12, and the metric 13.7, and the angles are $60^{\circ}, 55^{\circ}$, and $47.5^{\circ}$ respectively ; therefore each must have its special nut. As in these days engineers are constantly handling the products of other countries, and as two different systems of screws may be employed on the same machine, much time is wasted in finding the standard used and in trying to get a screw conforming to that standard.

A similar difficulty is experienced in wire and sheet metal gauges. It may be suggested that the time is ripe for the various bodies concerned to examine all sides of the question, with the view of securing the adoption of an international system of measures for all commercial purposes.

\section{Embryology of the Slime Eels*}

$\mathrm{T}$ HE Myxinoidea or slime eels have been the subject of inquiry and discussion by many investigators in both Europe and America. Much difference of opinion for a long time existed, and even yet remains, with regard both to the facts concerning them and to their interpretation. So little were these animals at first understood that the earliest investigators classified them with the worms. This error was early rectified, but great controversy continued to centre round such questions as whether the Myxinoids are or are not parasitic, whether they are primitive or degenerate, and whether they should be classified as Gnathostomata or Agnathostomata.

On the last question agreement had almost been reached, most morphologists and embryologists having placed them in the former group, when recently a sole investigator who has arisen in the field of myxinoid palæontology, stoutly claims for them a place in the latter. The excretory system has been described by some workers as a pronephros, by others as a pronephros which eventually becomes transformed into a mesonephros, and by still others as a small pronephros and a posterior segmental mesonephros which develops in the usual manner. The reproductive system, too, has been very extensively studied. Because of peculiarities in the structure of the generative organ, the myxinoids have long been believed to be functional hermaphrodites-in fact, they are still definitely stated to be so in even the most recent textbooks.

For many years the assistance of embryology in solving these and other problems connected with this difficult group was denied, because no one was able to find embryos developing in their natural environment or to obtain them by keeping the 'eels' in captivity. Neither did palæontology contribute towards their elucidation, for until quite recently no fossil cyclostome had been found-with the possible exception of Paloeospondylus, supposed by some to be a Devonian lamprey. This belief, however, was firmly rejected by Dr. Bashford Dean, by whom many valuable contributions to our knowledge of the Myxinoidea were made during the time that he was professor of zoology at Columbia University.

From examination of his notebooks, it seems quite

* The Bashford Dean Memorial Volume. "Archaic Fishes," Edited by E. W. Gudger. Article 3: The Genital System of the Myxinoidea; a Study based on Notes and Drawings of these Organs in Bdellostoma made by Bashford Dean. By Prof. J. Leroy Conel. Pp. 63-102+4 plates. (New York : American Museum of Natural History, 1931.) certain that this industrious and talented investigator had intended some day to publish still further information which he had gleaned, especially on the genital system of Bdellostoma. It is particularly fitting, therefore, that the Bashford Dean Memorial Volume on "Archaic Fishes" should contain this section on the Myxinoidea based on the unpublished data left by Dr. Dean in the form of notes, graphs, tables, and sixteen excellent drawings. This contribution to the volume is written by Prof. Leroy Conel, who for twelve years was associated with Dr. Dean in his work.

This author, before presenting Dr. Dean's notes and data (dealing mainly with the reproductive system of Bdellostoma), gives a brief but very useful review of the previous literature on the subject, in which the problems which Dr. Dean set out to solve are clearly indicated. Myxine glutinosa, the representative of the group mainly studied by previous workers, was stated by Nansen (1887) to be a functional protandric hermaphrodite. Cunningham (1891), though disagreeing with some of Nansen's observations, came to the same conclusion. In 1899 Dr. Dean published a paper in which he expressed grave doubts as to the truth of this assumption-doubts which were later supported in the publications of A. and K. E. Schreiner (1904-8). These authors held that, though undoubtedly hermaphrodite in structure, Myxine is functionally diøecious.

On account of this uncertainty concerning the true state of affairs in Myxine, Dr. Dean, in search of further evidence, turned his attention to other members of the group, Bdellostoma stouti and B. burgeri. In these he found the gonad of each individual examined to be definitely either a testis or an ovary, and concluded that both species of Bdellostoma, at least, are very rarely, if ever, hermaphrodite at any stage of their life history. This finding, he contended, made it still more difficult to believe that the closely related Myxine is a functional hermaphrodite. In 1896 , in order still more fully to investigate the life history of the Myxinoidea, Dr. Dean sought for, and succeeded in finding, a large number of embryos of $B$. stouti at Pacific Grove, in Monterey Bay, California - the first fairly complete series of myxinoid embryos ever collected. This material enabled him, in 1899 , to publish an account of the embryological development of this species. In 1900 and 1901 he made a similar, though less successful, attempt to

$$
\text { No. 3260, VoL. 129] }
$$

